\title{
Response of Garlic Plants (Allium sativum L.) to Foliar Application of Some Bio-Stimulants
}

\author{
M. E. M. Ahmed \\ Horticulture Department, Faculty of Agriculture, Tanta \\ University, Tanta, Egypt.
}

\begin{abstract}
7 HIS STUDY was carried out in a clay loamy soil, at the Experimental Farm, Fac. of Agric., Tanta Univ., Egypt, during $2011 / 2012$ and 2012/2013 seasons. The aim of this study was to evaluate the effect of some bio-stimulants, dry yeast (at three concentrations 2, 3 and 4 g.L $\mathrm{L}^{-1}$ ) and chitosan (at three concentrations 2, $4,6 \mathrm{ml} . \mathrm{L}^{-1}$ ) on growth, yield, quality and storability of "clone sids -40 " garlic plants. Bio-stimulants were applied at 30, 45,60 and 75 day s from planting date. The experiment was designed in a completely randomized blocks (CRB) with three replicates. Foliar application of dry yeast (3 and 4 g.L $\left.\mathrm{L}^{-1}\right)$ and chitosan (4 and $6 \mathrm{ml} . \mathrm{L}^{-1}$ ) effectively increased plant height, leaf number, leaves fresh weight, yield and its components in both seasons. Same treatments were positively affected N, P and K contents of leaves and bulbs, total carbohydrate and volatile oil of the bulbs in both seasons. Weight loss of the bulbs was the least with the application of chitosan ( 6 and $\left.4 \mathrm{ml} \cdot \mathrm{L}^{-1}\right)$ in both seasons. In general, foliar application of dry yeast ( 3 and 4 g. $\left.\mathrm{L}^{-1}\right)$ and chitosan (4 and 6 $\mathrm{ml} . \mathrm{L}^{-1}$ ) can be recommended to improve productivity, quality and storability of garlic plants grown in clay loamy soil.
\end{abstract}

Keywords: Bio-stimulate, Yeast, Chitosan, Productivity, Storability, garlic (Allium sativum L.).

Garlic (Allium sativum L.) is one of the most important vegetables in Egypt for both local consumption and exportation. It is cultivated for its flavor and medicinal properties, with the latter steadily arising worldwide (Collin, 2004). There are many factors, such as fertilization and bio-stimulating substances affect plant growth, productivity and bulb quality (El-Morsy, 2004). Using natural products, such as dry yeast and chitosan in garlic production has been adopted for safe agricultural system during the last years.

Yeast is considered as a natural source of phytohormones (especially cytokinins), vitamins, enzymes, minerals and amino acids. It has stimulatory effects on plant growth and productivity of beans (Barnett et al., 1990, Amer, 2004 and El-Tohamy \& El-Greadly, 2007), on eggplants (El-Tohamy et al., 2008), on tomatoes (Fathy et al., 2000), on peas (El-Desuki and El-Greadly, 2006), on potatoes (Taha \& Omar, 2010 and Ahmed et al., 2011), on cucumber (Shehata et al., 2012), and on garlic (Shalaby and El-Ramady, 2014). 
It also has a positive effect on cell division and enlargement, protein and nucleic acid synthesis, and chlorophyll formation of potatoes (Kraig \& Haber, 1980, and Castelfranco \& Beale, 1983). The cytokinins content of the yeast has an important role on plant stress resistance (Barnett et al., 1990).

Chitosan is a natural polymer derived from deacetylation of chitin. Chitin is readily available from shellfish waste from food processing. As a high molecular polymer, nontoxic, bioactive agent, Chitosan has become a useful appreciated compound due to its fungicidal effects and elicitation of defense mechanisms in plant tissues (Terry and Joyce, 2004 and Shehata et al., 2012). Chitosan coating is known for its ability to extend the storage life of fruits and vegetables. Chitosan forms a semipermeable film that regulates gas exchange, reduces respiration and transpiration rates, and slows down the ripening processes. (Shehata et al., 2012). This effect has been reported for numerous horticultural commodities such as tomatoes, strawberries, apples, mangoes, bananas, and bell peppers (Jiang \& Li, 2001 and Bautista-Baños et al., 2006). Foliar application of chitosan has been shown to stimulate plant growth (Kim, 2005), to increase vegetative growth, yield and quality of vegetable crops (Walker et al., 2004, Abdel-Mawgoud et al., 2010, Ghoname et al., 2010, El-Tanahy et al., 2012 and Fawzy et al., 2012), and to improve storability of fruits and vegetables (El Ghaouth et al., 1991).

Therefore, the aim of this study was to investigate the effect of some bio stimulants i.e. chitosan and yeast extract on growth, yield, bulb quality and storability of garlic under clay soil.

\section{Materials and Methods}

This experiment was carried out during two successive seasons, 2011/2012 and 2012/2013, at the Experimental Farm, Fac. of Agric., Tanta Univ., Egypt, on "clone sids-40" garlic plants. The soil type is loamy clay, and the chemical properties of the soil are presented in Table 1. Soil samples were collected at $25 \mathrm{~cm}$ below soil surface.

TABLE 1. Chemical physical analysis of soil before sowing according to Ryan et al. (1996).

\begin{tabular}{|c|c|c|c|}
\hline Sand $=14.98 \%$ & $\begin{array}{l}\mathrm{N}(\text { available })=45.7 \\
\mathrm{mg} / 100 \mathrm{~g}\end{array}$ & $\mathrm{Ca}++=5.99(\mathrm{meql})$ & $\begin{array}{l}\mathrm{HCO} 3-=4.81 \\
(\text { meql })\end{array}$ \\
\hline Silt $=38.45 \%$ & $\begin{array}{l}\mathrm{P}(\text { available })=7.2 \\
\mathrm{mg} / 100 \mathrm{~g}\end{array}$ & $\mathrm{Mg}++=6.13$ (meql) & $\begin{array}{l}\text { Cl- }=9.27 \\
\text { (meql) }\end{array}$ \\
\hline Clay $=46.57 \%$ & $\begin{array}{l}\mathrm{K} \text { (available) }=178.9 \\
\mathrm{mg} / 100 \mathrm{~g}\end{array}$ & $\mathrm{Na}+=14.61$ (meql) & $\begin{array}{l}\begin{array}{l}\text { SO4-- }=8.84 \\
(\text { meql) }\end{array}\end{array}$ \\
\hline \multicolumn{2}{|l|}{$\mathrm{pH}=7.84$} & \multicolumn{2}{|l|}{$\mathrm{EC}=1.3(\mathrm{ds} / \mathrm{m})$} \\
\hline
\end{tabular}

Egypt. J. Hort. Vol. 42, No.1 (2015) 
The experimental unit area was $12 \mathrm{~m}^{2}$, with four rows, $5 \mathrm{~m}$ length and $60 \mathrm{~cm}$ width. Garlic cloves were selected uniform in shape and size. The cloves were sown on both two sides of the rows at distance of $7 \mathrm{~cm}$ apart. Planting date was on October $3^{\text {rd }}$ and $8^{\text {th }}$ during the first and the second seasons, respectively. The cultural practices were done according to the recommendation of Minis try of Agriculture, Egypt.

\section{Treatments and experimental design}

The experiment included 7 treatments from some bio-stimulants as follows: Three different concentrations of yeast extract $\left(2,3\right.$ and 4 g. $\left.\mathrm{L}^{-1}\right)$, chitosan extract $\left(2,4,6 \mathrm{ml.} \mathrm{L}^{-1}\right)$ and control were applied at 30, 45, 60 and 75 days from sowing date in both seasons. Tap water was sprayed to the control of plants. The experiment was designed in a complete randomized blocks (CRB) with three replicates.

\section{Data recorded}

Ten plants were selected randomly from each replicate at 145 days after planting to measure plant height $(\mathrm{cm})$, number of leaves per plant, and leaf fresh and dry weight (g) per plant. At harvest (190 days after sowing), all plants for each replicate were harvested and the total yield per feddan was calculated after curing for 7 days. A random sample of 10 bulbs was taken from each replicate to determine bulb fresh weight ( $\mathrm{g}$ ), number of cloves/ bulb, and bulbing ratio. Bulbing ratio was calculated according to Mann $(1952)=$ Neck diameter $(\mathrm{cm}) /$ Bulb diameter $(\mathrm{cm})$. Total nitrogen $(\mathrm{N})$, phosphorus $(\mathrm{P})$ and potassium $(\mathrm{K})$ in dry matter of leaves and bulbs, and the total hydrolysable carbohydrates in dry bulbs were determined according to the methods described in A.O.A.C (1995). Volatile oil content was determined in fresh garlic cloves, also, according to the methods described in A.O.A.C (1995).

After curing, random samples of $10 \mathrm{~kg}$ of garlic plants were taken from each replicate and stored for 9 months at normal room conditions. Monthly average air temperature and relative humidity during storage time are presented in Table (2). The percentages of total weight loss were calculated every two months up to the end of the storage period (1, 3, 5, 7 and 9 months). Sprouting and decay were recorded only at the end of storage period.

\section{Statistical analysis}

Data were analyzed by MSTATC computer software program (Bricker, 1991) using ANOVA with the least significant difference (LSD) at the $P \leq 0.05$. 
TABLE 2. Monthly average of maximum and minimum air temperature and relative humidity during storage period.

\begin{tabular}{|l|c|c|c|c|c|c|}
\hline \multirow{2}{*}{ Month } & $\begin{array}{c}\text { Maximum } \\
\text { temperature } \\
\left({ }^{\circ} \mathbf{C}\right)\end{array}$ & $\begin{array}{c}\text { Minimum } \\
\text { temperature } \\
\left({ }^{\circ} \mathbf{C}\right)\end{array}$ & $\begin{array}{c}\text { Relative } \\
\text { humidity } \\
(\mathbf{R H \%})\end{array}$ & $\begin{array}{c}\text { Maximum } \\
\text { temperature } \\
\left({ }^{\circ} \mathbf{C}\right)\end{array}$ & $\begin{array}{c}\text { Minimum } \\
\text { temperature } \\
\left({ }^{\circ} \mathbf{C}\right)\end{array}$ & $\begin{array}{c}\text { Relative } \\
\text { humidity } \\
(\mathbf{R H \%})\end{array}$ \\
\cline { 2 - 8 } & \multicolumn{2}{|c|}{$\mathbf{2 0 1 2}$} & \multicolumn{4}{|c|}{$\mathbf{2 0 1 3}$} \\
\hline April & 33.24 & 15.06 & 30.05 & 29.13 & 12.38 & 38.94 \\
\hline May & 37.01 & 18.50 & 30.71 & 35.53 & 18.00 & 32.13 \\
\hline June & 41.33 & 21.83 & 31.32 & 37.24 & 20.05 & 33.51 \\
\hline July & 42.71 & 23.67 & 33.52 & 37.21 & 20.26 & 38.98 \\
\hline Sugust & 41.75 & 24.24 & 34.08 & 38.10 & 21.26 & 37.98 \\
\hline September & 38.05 & 21.66 & 41.79 & 35.17 & 19.79 & 44.50 \\
\hline October & 33.87 & 20.30 & 47.08 & 30.17 & 15.58 & 48.14 \\
\hline Dovember & 27.48 & 16.85 & 55.48 & 27.11 & 14.62 & 51.55 \\
\hline December & 21.75 & 11.26 & 53.67 & 20.09 & 8.48 & 54.71 \\
\hline
\end{tabular}

Data recorded by Gemmeza Meteorological Station, Gharbia governorate, Egypt.

\section{Results and Discussion}

\section{Growth characteristics}

Foliar application of dry yeast (2,3 and 4 g.L.-1) and chitos an $\left(2,4\right.$ and 6 ml.L $\left.\mathrm{L}^{-1}\right)$ was significantly improved leaf fresh weight, plant height, and the number of leaves per plant, compared to the control during both seasons (Table 3). The most pronounced effect was noticed with the highest concentrations of both dry yeast and chitosan, but no effect was noticed on plant dry weight at any concentration during both seasons. The positive effect of yeast extract on plant vegetative characteristics was mainly due to the natural content of cytokinins, enzymes, amino acids, vitamins and mineral nutrients (Khedr and Farid, 2002, Mahmoud, 2001) that positively affect cell division and elongation, nucleic acid synthesis, protein and chlorophyll formation (Kraig \& Haber, 1980 and Castelfranco \& Beale, 1983). Improving growth and productivity of vegetable crops by application of yeast extract were recorded by several studies such as (El-Tohamy \& El-Greadly, 2007 and Fawzy et al., 2010) on beans, (El-Tohamy et al., 2008) on eggplant, (Fathy et al., 2000) on tomatoes, (El-Desuki and El-Greadly, 2006) on pea, (Ghoname et al., 2010) on sweet pepper, (Ahmed et al., 2011 and Ahmed et al., 2013) on potato, Shehata et al. (2012) on cucumber and Shalaby and El-Ramady (2014) on garlic.

The stimulatory effect of chitosan on vegetative growth and bulb growth is may be due to some amino acids components that required for plant growth. Chitosan application was proved to stimulate plant growth and production in strawberry (Abdel-Mawgoud et al., 2010), on sweet pepper (Ghoname et al., 2010), on cowpea (El-Tanahy et al., 2012), and on cucumber (Shehata et al., 2012).

Egypt. J. Hort. Vol. 42, No.1 (2015) 
TABLE 3. Effect of some bio-stimulants on the vegetative growth characteristics of garlic plants during 2011/2012 and 2012/2013 seasons.

\begin{tabular}{|c|c|c|c|c|c|c|c|c|}
\hline \multirow[b]{2}{*}{ Treatments } & \multicolumn{4}{|c|}{ 2011/2012 } & \multicolumn{4}{|c|}{$2012 / 2013$} \\
\hline & $\begin{array}{r}\text { Plant } \\
\text { height } \\
(\mathrm{cm})\end{array}$ & $\begin{array}{c}\begin{array}{c}\text { No. } \\
\text { of } \\
\text { leaves } \\
\text { plant }\end{array} \\
\end{array}$ & $\begin{array}{c}\text { Leaves } \\
\text { fresh } \\
\text { wt. } \\
\text { (g) }\end{array}$ & $\begin{array}{c}\text { Leaves } \\
\text { dry } \\
\text { wt. } \\
(\%)\end{array}$ & $\begin{array}{c}\text { Plant } \\
\text { height } \\
(\mathrm{cm})\end{array}$ & $\begin{array}{c}\begin{array}{c}\text { No. } \\
\text { of } \\
\text { leaves/ } \\
\text { plant }\end{array} \\
\end{array}$ & $\begin{array}{c}\text { Leave } \\
\text { fresh wt. } \\
\text { (g) }\end{array}$ & $\begin{array}{c}\text { Leaves } \\
\text { Dry wt. } \\
(\%)\end{array}$ \\
\hline Yeast $\left(2\right.$ g. $\left.1^{-1}\right)$ & 79.67 & 9.52 & 28.71 & 13.77 & 75.43 & 9.21 & 29.34 & 14.38 \\
\hline Yeast $\left(3 \mathrm{~g} .1^{-1}\right)$ & 84.32 & 10.11 & 30.51 & 13.91 & 79.99 & 10.11 & 32.15 & 14.55 \\
\hline Yeast $\left(4\right.$ g. $\left.1^{-1}\right)$ & 88.12 & 10.57 & 31.38 & 14.09 & 82.34 & 10.75 & 33.21 & 14.75 \\
\hline Chitosan $\left(2 \mathrm{ml} .1^{-1}\right)$ & 78.03 & 9.99 & 28.85 & 13.54 & 74.11 & 8.75 & 29.42 & 14.21 \\
\hline Chitosan $\left(4 \mathrm{ml} . \mathrm{1}^{-1}\right)$ & 83.11 & 9.91 & 31.09 & 13.72 & 78.47 & 9.86 & 31.99 & 14.05 \\
\hline Chitosan $\left(6 \mathrm{ml} .1^{-1}\right)$ & 86.21 & 10.26 & 31.77 & 13.98 & 80.91 & 10.38 & 32.53 & 14.51 \\
\hline Control & 74.98 & 8.98 & 28.1 & 13.47 & 69.88 & 8.11 & 28.52 & 13.93 \\
\hline L.S.D. $(P \leq 5 \%)$ & 3.01 & 0.34 & 1.05 & n.s & 2.17 & 0.23 & 0.99 & n.s \\
\hline
\end{tabular}

Total yield and yield components

All bio-stimulants treatments clearly improved total yield, bulb weight and bulb diameter compared to the control (Table 4). The application of dry yeast $\left(4 \mathrm{mg} . \mathrm{L}^{-1}\right)$ and chitosan $\left(6 \mathrm{ml} . \mathrm{L}^{-1}\right)$ had the most pronounced effect on total yield, 8.299 and 8.189 , ton/ feddan in the first season, and 8.359 and 8.254 ton/ feddan in the second season, respectively. The same treatments increased bulb weight and diameter significantly in both seasons. The lowest yield was obtained from the control in both seasons. Bulbing ratio and number of cloves were not significantly affected with any treatments in both seasons. The positive effect of dry yeast is may be attributed to the increase in plant nutrient contents, amino acids, vitamin B and cytokinins (Glick, 1995 and Fathy \& Farid, 1996). Vitamins and amino acids increase the metabolic processes and the levels of endogenous hormones, i.e. $\mathrm{GA}_{3}$ and IAA, which affect the final bulb weight and size (Chaliakhyan, 1957 and Sarhan \& Abdullah, 2010). Similar trend of results, as previously, were reported by several scientists for several crops (Shehata et al., 2012 on cucumber, Ahmed et al., 2013 on potato and Shalaby and El-Ramady, 2014 on garlic).

Chitosan has a stimulatory effect on plant growth, and improve the total yield, as well as plant resistance to diseases in several vegetable and fruit crops (Shehata et al., 2012). The increase in bulbs yield could be attributed to the increase in some amino acids and nutrients required for growth. This results are in agreement with previously reported results on strawberry (Abdel-Mawgoud et al., 2010), sweet pepper (Ghoname et al., 2010), cowpea (El-Tanahy et al., 2012), and cucumber (Shehata et al., 2012). 
TABLE 4. Effect of some bio-stimulants on yield and quality of garlic bulbs during 2011/2012 and 2012/2013 seasons.

\begin{tabular}{|c|c|c|c|c|c|c|c|c|c|c|}
\hline \multirow[b]{2}{*}{ Treatments } & \multicolumn{5}{|c|}{ 2011/2012 } & \multicolumn{5}{|c|}{ 2012/2013 } \\
\hline & $\begin{array}{l}\text { Total } \\
\text { bulb } \\
\text { yield } \\
\text { (ton } \\
\left.\text { /fed. }{ }^{*}\right)\end{array}$ & $\begin{array}{c}\text { Bulb } \\
\text { fresh } \\
\text { wt. } \\
\text { (g) }\end{array}$ & $\begin{array}{c}\text { Cloves } \\
\text { no. / } \\
\text { bulb }\end{array}$ & $\begin{array}{l}\text { Bulb } \\
\text { diam- } \\
\text { eter } \\
(\mathrm{cm})\end{array}$ & $\begin{array}{c}\text { Bulb- } \\
\text { ing } \\
\text { ratio }\end{array}$ & $\begin{array}{l}\text { Total } \\
\text { Bulb } \\
\text { Yield } \\
\text { (ton } \\
\text { fed. }^{*} \text { ) }\end{array}$ & $\begin{array}{c}\text { Bulb } \\
\text { fresh } \\
\text { wt. } \\
\text { (g) }\end{array}$ & $\begin{array}{c}\text { Cloves } \\
\text { no. / } \\
\text { bulb }\end{array}$ & $\begin{array}{l}\text { Bulb } \\
\text { diam- } \\
\text { eter } \\
(\mathrm{cm})\end{array}$ & $\begin{array}{c}\text { Bulb- } \\
\text { ing } \\
\text { ratio }\end{array}$ \\
\hline Yeast $\left(2 \mathrm{~g} .1^{-1}\right)$ & 7.917 & 81.65 & 22.58 & 6.04 & 0.23 & 8.085 & 75.23 & 21.76 & 5.81 & 0.22 \\
\hline Yeast $\left(3 \mathrm{~g} .1^{-1}\right)$ & 8.124 & 87.12 & 21.95 & 6.25 & 0.23 & 8.250 & 84.34 & 22.56 & 6.04 & 0.21 \\
\hline Yeast $\left(4\right.$ g. $\left.1^{-1}\right)$ & 8.299 & 90.23 & 22.99 & 6.52 & 0.22 & 8.359 & 88.99 & 23.55 & 6.15 & 0.19 \\
\hline Chitosan $\left(2 \mathrm{ml} .1^{-1}\right.$ & 7.927 & 79.89 & 20.65 & 5,99 & 0.23 & 8.041 & 74.21 & 21.61 & 5.81 & 0.23 \\
\hline Chitosan $\left(4 \mathrm{ml} .1^{-1}\right.$ & 8.055 & 85.87 & 20.37 & 6.20 & 0.22 & 8.187 & 81.34 & 24.00 & 6.05 & 0.21 \\
\hline Chitosan $\left(6 \mathrm{ml} .1^{-1}\right.$ & 8.189 & 87.11 & 23.19 & 6.34 & 0.21 & 8.254 & 84.45 & 23.01 & 6.11 & 0.20 \\
\hline Control & 7.763 & 76.11 & 18.95 & 5.41 & 0.25 & 7.959 & 70.21 & 20.11 & 5.32 & 0.24 \\
\hline L.S.D. $(P \leq 5 \%)$ & 0.205 & 2.15 & n.s & 0.51 & n.s & 0.175 & 1.99 & n.s & 0.45 & n.s \\
\hline
\end{tabular}

${ }^{*}$ Fed. $=4200 \mathrm{~m}^{2}$.

\section{Chemical constituents}

The total content of $\mathrm{N}, \mathrm{P}, \mathrm{K}$ in leaves and bulbs, as well as total carbohydrates and voliate oil content in bulbs were increased as a resullt of foliar application with all bio-stimulants treatments compared to the control in both seasons. Foliar application of dry yeast at $4 \mathrm{mg} . \mathrm{L}^{-1}$ resulted in the highest values of $\mathrm{N}$ content in leaves (1.86 and 1.83\%), $\mathrm{N}$ content in bulbs (1.47 and 1.44\%), and total carbohydrate content (83.2 and 81.32) in bulbs in both seasons, respectively (Tables 5 and 6). This effect of dry yeast is may be attributed to its high contents of carbohydrates, amino acids, sugars, fatty acids, proteins, hormones, macro and micro- nutrients (Khedr and Farid, 2002). The highest values of $\mathrm{P}(0.77$ and $0.71 \%$ in leaves, 0.54 and $0.55 \%$ in bulbs) and $\mathrm{K}$ (2.69 and $2.53 \%$ in leaves, 1.55 and $1.51 \%$ in bulbs) content were obtained by foliar application of chitosan at $6 \mathrm{ml} . \mathrm{L}^{-1}$ in 2011/2012 and 2012/2013 seasons, respectively. All results were significant in both seasons, but $\mathrm{K}$ contents of leaves and bulbs were insignificant in the first season only (Tables 5 and 6).

The obtained results are in harmony with those of Ghoname et al. (2010), Fawzy et al. (2010), Ahmed et al. (2011) and Shehata et al. (2012) who studied the effects of application of yeast on sweet pepper, Snap bean, potato, cucumber and garlic plants, respectively. The results of the effect of chitos an on chemical content are in agreement with results, which obtained with Abdel-Mawgoud et al. (2010) and Shehata et al. (2012).

Egypt. J. Hort. Vol. 42, No.1 (2015) 
TABLE 5. Effect of some bio-stimulants on chemical contents of garlic leaves during 2011/2012 and 2012/2013 seasons.

\begin{tabular}{|c|c|c|c|c|c|c|}
\hline \multirow[b]{2}{*}{ Treatments } & \multicolumn{3}{|c|}{$2011 / 2012$} & \multicolumn{3}{|c|}{$2012 / 2013$} \\
\hline & $\underset{(\%)}{\mathbf{N}}$ & $\underset{(\%)}{P}$ & $\underset{(\%)}{\mathbf{K}}$ & $\begin{array}{c}\mathbf{N} \\
(\%)\end{array}$ & $\begin{array}{c}P \\
(\%)\end{array}$ & $\underset{(\%)}{\mathbf{K}}$ \\
\hline Yeast $\left(2 \mathrm{~g} .1^{-1}\right)$ & 1.71 & 0.55 & 2.64 & 1.75 & 0.49 & 2.39 \\
\hline Yeast $\left(3\right.$ g. $\left.1^{-1}\right)$ & 1.84 & 0.59 & 2.65 & 1.82 & 0.55 & 2.42 \\
\hline Yeast $\left(4 \mathrm{~g} .1^{-1}\right)$ & 1.86 & 0.64 & 2.70 & 1.83 & 0.59 & 2.41 \\
\hline Chitosan $\left(2 \mathrm{ml}^{-1} \mathrm{1}^{-1}\right)$ & 1.70 & 0.62 & 2.66 & 1.73 & 0.60 & 2.47 \\
\hline Chitosan $\left(4 \mathrm{ml} .1^{-1}\right)$ & 1.78 & 0.71 & 2.66 & 1.79 & 0.68 & 2.51 \\
\hline Chitosan $\left(6 \mathrm{ml} .1^{-1}\right)$ & 1.81 & 0.77 & 2.69 & 1.81 & 0.71 & 2.53 \\
\hline Control & 1.66 & 0.51 & 2.59 & 1.69 & 0.42 & 2.38 \\
\hline L.S.D. $(P \leq 5 \%)$ & 0.03 & 0.06 & n.s & 0.02 & 0.05 & 0.04 \\
\hline
\end{tabular}

TABLE 6. Effect of some bio stimulants on chemical contents of garlic bulbs during 2011/2012 and 2012/2013 seasons.

\begin{tabular}{|c|c|c|c|c|c|c|c|c|c|c|}
\hline \multirow[b]{2}{*}{ Treatments } & \multicolumn{5}{|c|}{$2011 / 2012$ season } & \multicolumn{5}{|c|}{$2012 / 2013$ season } \\
\hline & $\begin{array}{c}\mathbf{N} \\
(\%)\end{array}$ & \begin{tabular}{|c|}
$P$ \\
$(\%)$
\end{tabular} & \begin{tabular}{|c|}
$\mathbf{K}$ \\
$(\%)$
\end{tabular} & \begin{tabular}{|c|}
$\begin{array}{c}\text { Total } \\
\text { carbo- } \\
\text { hydrate } \\
(\mathrm{mg} / \\
\mathbf{1 0 0 g})\end{array}$ \\
\end{tabular} & $\begin{array}{c}\text { Volatil } \\
\text { e oil } \\
\text { (g/100 } \\
\text { g f.w.) }\end{array}$ & $\begin{array}{c}\mathbf{N} \\
(\%)\end{array}$ & $\begin{array}{c}\mathrm{P} \\
(\%)\end{array}$ & \begin{tabular}{|c|}
$\mathbf{K}$ \\
$(\%)$
\end{tabular} & $\begin{array}{c}\text { Total } \\
\text { carbo- } \\
\text { hydrate } \\
(\mathbf{m g} / \\
\mathbf{1 0 0 g}) \\
\end{array}$ & $\begin{array}{c}\text { Volatile } \\
\text { oil } \\
\text { (g/100g } \\
\text { f.w. })\end{array}$ \\
\hline Yeast $\left(2\right.$ g. $\left.1^{-1}\right)$ & 1.42 & 0.39 & 1.49 & 73.76 & 0.331 & 1.35 & 0.42 & 1,40 & 70.55 & 0.328 \\
\hline Yeast $\left(3\right.$ g. $\left.1^{-1}\right)$ & 1.46 & 0.45 & 1.52 & 80.59 & 0.357 & 1.42 & 0.44 & 1.40 & 77.78 & 0.352 \\
\hline Yeast $\left(4\right.$ g. $\left.1^{-1}\right)$ & 1.47 & 0.46 & 1.54 & 83.02 & 0.379 & 1.44 & 0.47 & 1.43 & 81.32 & 0.361 \\
\hline Chitosan $\left(2 \mathrm{ml}^{-1} \mathrm{1}^{-1}\right)$ & 1.38 & 0.49 & 1.51 & 69.99 & 0.342 & 1.35 & 0.46 & 1.45 & 68.99 & 0.349 \\
\hline Chitosan $\left(4 \mathrm{ml}^{-1} \mathrm{1}^{-1}\right)$ & 1.42 & 0.51 & 1.51 & 78.99 & 0.371 & 1.39 & 0.50 & 1.49 & 74.32 & 0.368 \\
\hline Chitosan $\left(6 \mathrm{ml} .1^{-1}\right)$ & 1.42 & 0.54 & 1.55 & 79.56 & 0.386 & 1.42 & 0.55 & 1.51 & 78.21 & 0.409 \\
\hline Control & 1.34 & 0.33 & 1.44 & 67.21 & 0.329 & 1.29 & 0.37 & 1.39 & 63.92 & 0.317 \\
\hline L.S.D. $(P \leq 5 \%)$ & 0.02 & 0.04 & n.s & 0.52 & 0.009 & 0.03 & 0.05 & 0.01 & 0.45 & 0.015 \\
\hline
\end{tabular}

\section{Storability}

The storability of garlic bulbs was markedly influenced by foliar application of chitosan and yeast (Fig. 1, 2, 3 and 4). In general, chitosan treatments had better storability effect, compared to the control and other treatments. i.e., reduced total weight loss, decay and sprouting percentages of garlic bulbs during storage periods in both seasons. The percentage of weight loss was steadily increased until 7 months of storage, then, it rapidly increased until the end of storage (Fig. 1 and 2). These results may be due to the stimulatory effect of chitosan on growth parameters, which may be reflected on quality and storability of garlic bulbs during storage (Table 3). The effect of chitosan on garlic bulbs storability may be due to the positive effect of chitosan coatings effect that extend the storage through the reduction of respiration rate and water loss (Shehata et al., 2012). 


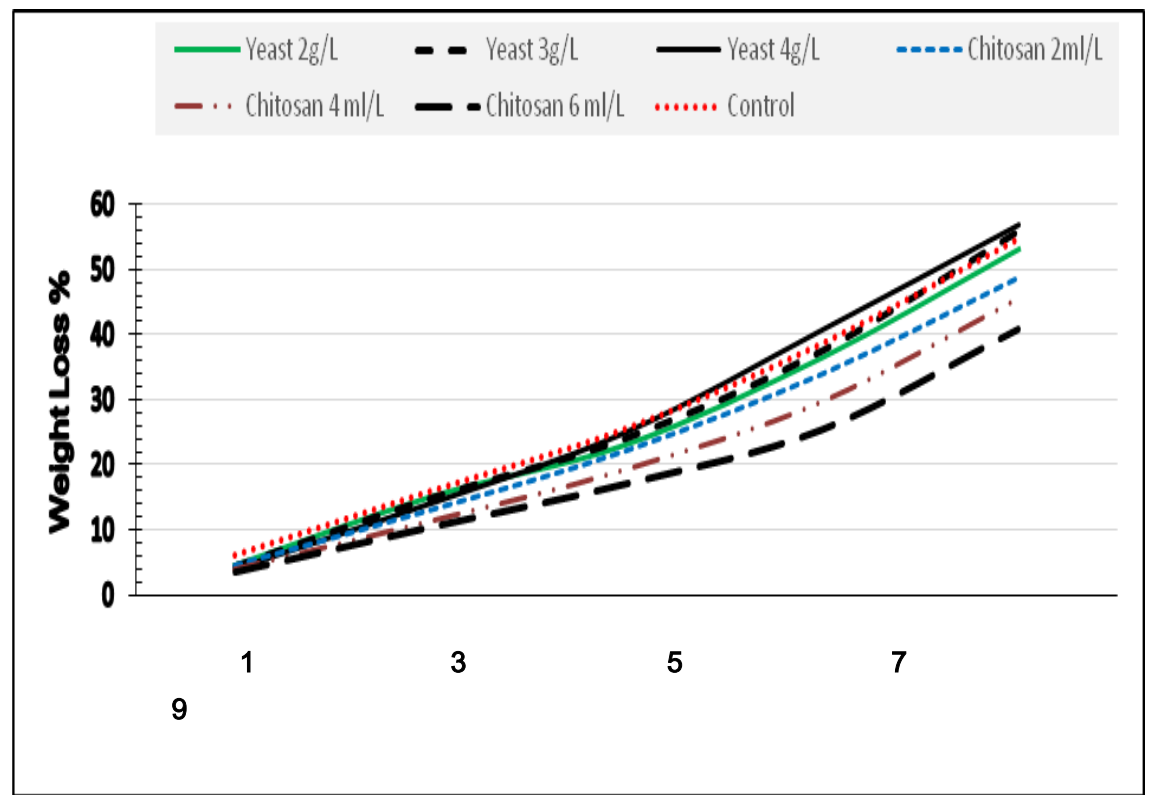

Fig. 1. Effect of some bio-stimulants on weight loss (\%) of garlic bulbs during 2011/2012 season.

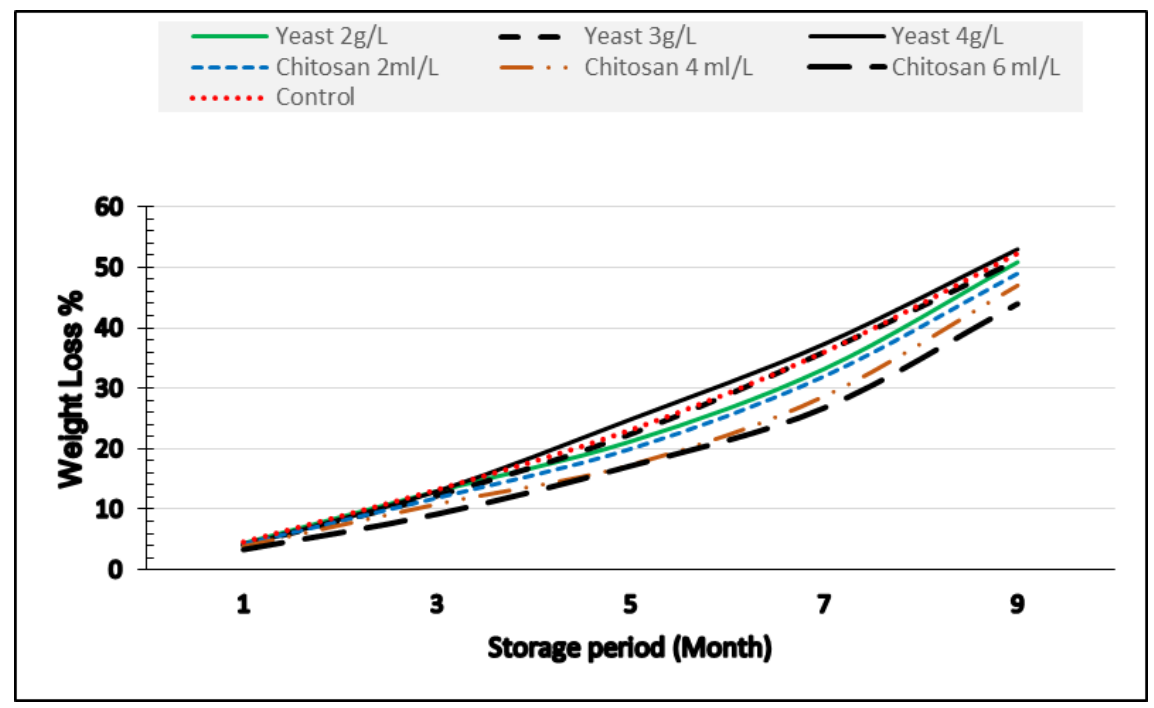

Fig. 2. Effect of some bio-stimulants on weight loss (\%) of garlic bulbs during 2012/2013 season.

Egypt. J. Hort. Vol. 42, No.1 (2015) 


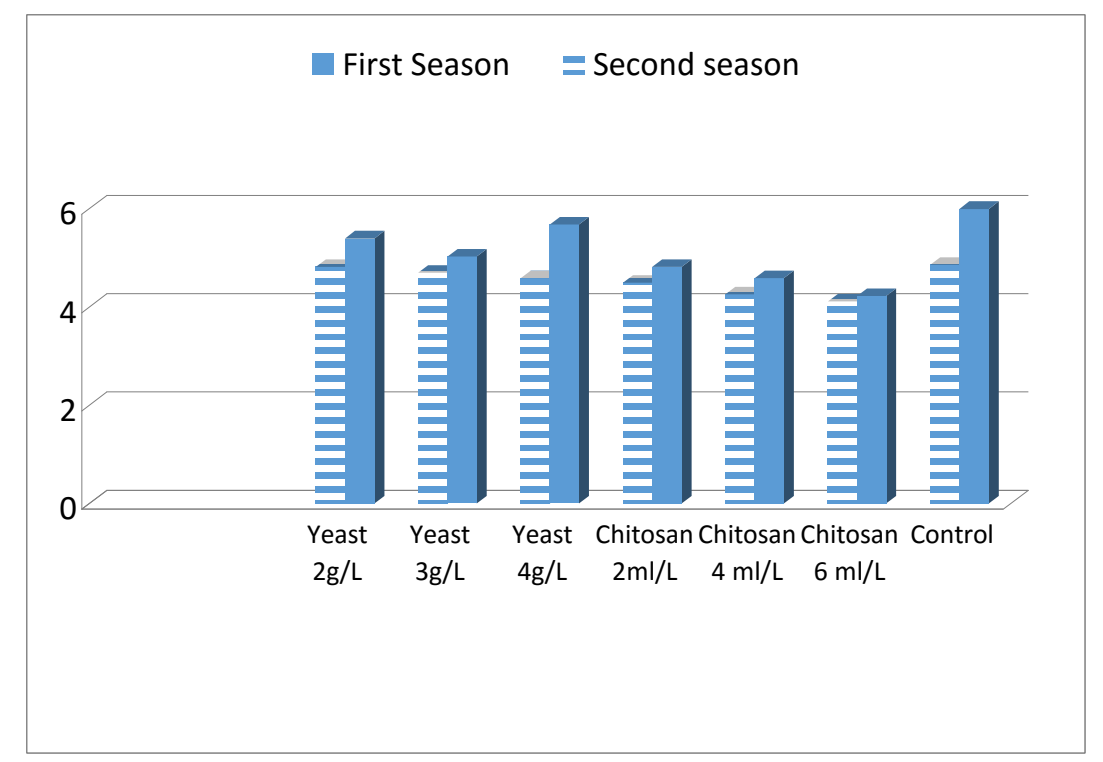

Fig. 3. Effect of some bio-stimulants on Sprouting (\%) of garlic bulbs during 2011/2012 and 2012/2013 seasons.

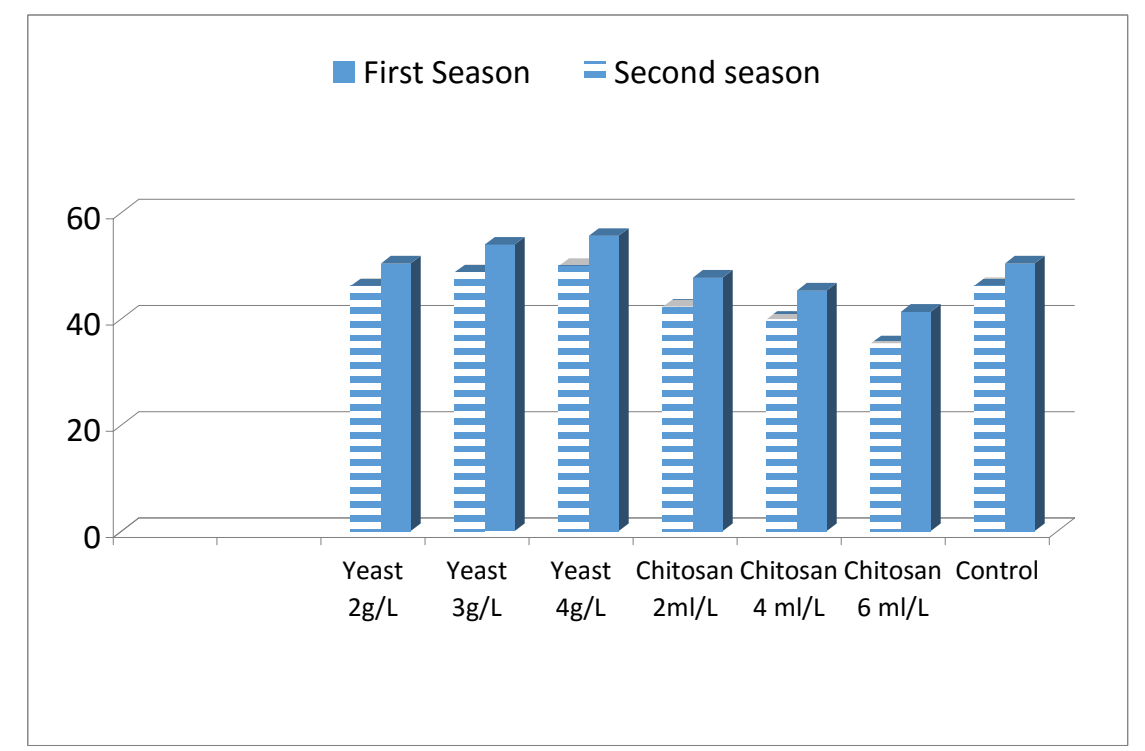

Fig. 4. Effect of some bio-stimulants on decay (\%) of garlic bulbs during 2011/2012 and 2012/2013 seasons. 


\section{Conclusion}

From the previous results it could be concluded that the foliar application of dry yeast $\left(3\right.$ and $\left.4 \mathrm{~g} . \mathrm{L}^{-1}\right)$ and chitosan $\left(4\right.$ and $\left.6 \mathrm{ml} \cdot \mathrm{L}^{-1}\right)$ can be used to enhance yield, quality andstorability of garlic plants grown in loamy clay soil.

\section{References}

Abdel-Mawgoud, A.M.R., Tantawy, A.S., El-Nemr, M.A. and Sassine, Y.N. (2010) Growth and yield Responses of strawberry plants to Chitosan application. European J. Sci. Res., 39 (1) , 170- 170-177.

Ahmed, A.A., Abd El-Baky, M.M.H., Zaki, M.F. and Faten, S. Abd El-Aal (2011) Effect of foliar application of active yeast extract and zinc on growth, yield and quality of potato plant (Solanum tuberosum L). J. Appl. Sci. Res., 7 (12), 2479-2488.

Ahmed, A.A., Abd El-Baky, M.M.H., Helmy, Y.I. and Shafeek, M.R. (2013) Improvement of potato growth and productivity by application of bread yeast and manganese. J. Appl. Sci., Res., 9 (8), 4896-4906

Amer, S.S.A. (2004) Growth, green pods yield and seeds yield of common bean (Phaseolus vulgaris L) as affected by active dry yeast, salicylic acid and their interaction. J. Agric. Sci., Mansoura Univ., 29 (3), 1407-1422.

A.O.A.C. (1995) "Official Method of Analysis" $16^{\text {th }}$ ed., Association of Official Analy tical Chemists International, Arlington Virginia, USA.

Barnett, J.A., R.W. Payne, R.W. and D. Yarrow, D. (1990) "Yeasts, Characteristics and Identification", Cambridge University Press, London, 999 p.

Bautista-Baños, S., Hernández-Lauzardo, A.N. and Velázquez-del Valle, M.G. (2006) Chitosan as a potential natural compound to control pre and post harvest diseases of horticultural commodities. Crop Protection, 25, 108-118.

Bricker, B. (1991) MSTATC: A micro computer program from the design management and analy sis of agronomic research experiments. Michigan State Univ., USA.

Castelfranco, P.A. and Beale, S.I. (1983) Chlorophyll biosynthesis recent advances and areas of current interest. Ann. Rev. Plant Physio., 34, 241-278.

Chaliakhyan, M.K. (1957) Effect of vitamins on growth and development of plants. Dokly Akad. Nauk. SSSK, 3, 894-897.

Collin, H.A. (2004) Garlic and cardiovascular diseases. In: Amoldi, A., Dadds, F. (Ed.) Functional foods, diet, cardiovascular diseases and diabetes. Woodhead Pub., Abington, Cambridge, UK.

El-Desuki, M. and El-Greadly, N.H.M. (2006) Response of pea plants to foliar application of yeast extract. J. Agric. Sci., Mansoura Univ., 31 (10), 6667-6674. 
El Ghaouth, A., Arul, J., Ponnampalam, R. and Boulet, M. (1991) Chitosan coating effect on storability and quality of fresh strawberries. J. Food Sci., 56, 1618-20.

El-Morsy, A.H.A. (2004) Effect of some potassium levels and mepiquat chloride (pix) on growth, yield and its quality of garlic (Allium sativum, L). J. Agric. Sci. Mansoura Univ., 29 (7), 4149-4158.

El-Tanahy, A.M.M., Asmaa R. Mahmoud, Mona M. Abd El-Mouty and Aisha H. Ali (2012) Effect of chitosan doses and nitrogen sources on the growth, yield and seed quality of cowpea. Australian J. Basic and Appl. Sci., 6 (4), 115-121.

El-Tohamy, W.A., El-Abagy, H.M. and El-Greadly, N.H.M. (2008) Studies on the effect of Putrescine, Yeast and Vitamin $\mathrm{C}$ on growth, yield and physiological responses of eggplant (Solanum melongena L) under sandy soil conditions. Australian J. Basic and Appl. Sci., 2 (2), 296-300.

El-Tohamy, W.I.A. and El-Greadly, N.H.M. (2007) Phy siological responses, growth, yield and quality of Snap Beans in response to foliar application of Yeast, Vitamin E and Zinc under sandy soil conditions. Australian J. of Basic and Appl. Sci., 1(3), 294299.

Fathy, E.S.L. and Farid, S. (1996) The possibility of using vitamin B and yeast to delay senescence and improve growth and yield of common beans (Phaseolus vulgaris L) $J$. Agric. Sci. Mansoura Univ., 21 (4), 1415-1423.

Fathy, El- S.L., Farid, S. and El-Desouky, S.A. (2000) Induce cold tolerance of outdoor tomatoes during early summer season by using adenosine triphosphate (ATP), yeast, other material and chemical treatments to improve their fruiting and yield. J. Agric. Sci., Mansoura Univ., 25 (1), 377-401.

Fawzy, Z.F., El-Bassiony, A.M., Behairy, A.G. and Helmy, Y.I. (2010) Effect of Foliar Spraying by Some Bio and Organic Compounds on Growth, Yield and Chemical Composition of Snap Bean Plant. J. Appl. Sci. Res., 6 (12), 2269-2274.

Fawzy, Z.F., El-Shal, Z.S., Li Yunsheng, Ouyang Zhu and Omaima M. Sawan (2012) Response of Garlic (Allium sativum, L) plants to foliar spraying of some biostimulants under sandy soil condition. J. Appl. Sci. Res., 8(2), 770-776.

Ghoname, A.A., El-Nemr, M.A., Abdel-Mawgoud, A.M.R. and El-Tohamy, W.A. (2010) Enhancement of sweet pepper crop growth and production by application of biological, organic and nutritional solutions. Res. J. Agric. Biol. Sci., 6 (3), 349-355.

Glick. B.R. (1995) The enhancement of plant growth by free living bacteria. Canad. J. Microbiology, 41, 109-117.

Jiang, Y.M. and Li, Y.B. (2001) Effects of chitosan coating on postharvest life and quality of longan fruit. Food Chemistry, 73, 139-143.

Kraig, E. and Haber, J.E. (1980) Messenger ribonucleic acid and protein metabolism during sporulation of Saccharomyces cerevisiae. J. Bacterial., 144, 1098-1112. 
Khedr, Z.M.A. and Farid, S. (2002) Response of naturally virus infected tomato plants to yeast extract and phosphoric acid application. Annals of Agric. Sci. Moshtohor. Egypt, 38 (2), 927-939.

Kim, H.J. (2005) Characterization of bioactive compounds in essential oils, fermented anchovy sauce, and edible plants, and, induction of phy tochemicals from edible plants using methyl jasmonate (MeJA) and chitosan. Ph.D. Thesis, Clemson Univ., USA, $178 \mathrm{pp}$

Mahmoud, T.R. (2001) Botanical studies on growth and germination of Magnolia (Magnolia grandiflora L.) Plants. M.Sc. Thesis, Fac. Agric., Moshtohor, Zagazig Univ., 103 pp.

Mann, L.K. (1952) Anatomy of the garlic bulb and factors affecting bulb development. Hilgardia, 21, 195-228.

Ryan, J., Garabet, S., Harmsen, K. and Rashid, A. (1996) A soil and plant analysis manual. Adapted for the West Asia and North Africa Region. International Center for Agricultural Research in the Dry Areas, ICARDA, Aleppo, Syria 140 pp.

Sarhan, T. and Abdullah, O.K. (2010) Effect of Azotobacter inoculation, dry bread yeast suspension and varying levels of urea on growth of potato $\mathrm{Cv}$. Desiree. $\mathrm{html} / \mathrm{www}$.tropentage.de/2010/abstracts/full/628.

Shalaby, T.A. and El-Ramady, H. (2014) Effect of foliar application of bio-stimulants on growth, yield, components, and storability of garlic (Allium sativum L.). A. J. C. Sci., 8 (2), 271-275

Shehata, S.A., Fawzy, Z.F. and El-Ramady, H.R. (2012) Response of cucumber plants to foliar application of chitosan and yeast under greenhouse. Australian J. Basic Appl. Sci., 6 (4), 63-71.

Taha, S. and Omar, K.A. (2010) Effect of Azotobacter Inoculation, dry dread yeast suspension and varying levels of urea on growth of potato cv. Desiree. Tropentag, September 14-16, Zurich "World Food System- A Contribution from Europe.

Terry, L.A. and Joyce, D.C. (2004) Elicitors of induced disease resistance in postharvest horticultural crops: a brief review. Postharvest Biology and Technology, 32, 1-13.

Walker, R., Morris, S., Brown, P. and Gracie, A. (2004) Evaluation of potential for chitosan to enhance plant defense. Publication No. 04.of Rural Industries Res. and Development Corporation. Australia, p. 55. 


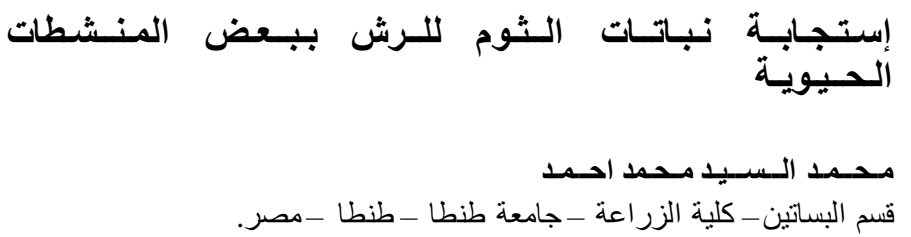

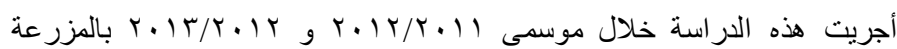

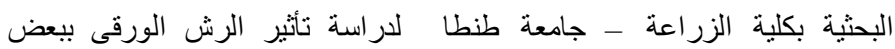

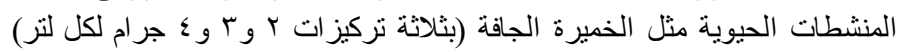

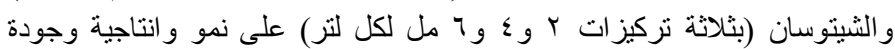

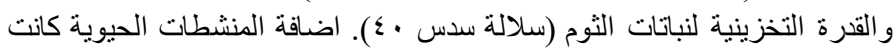

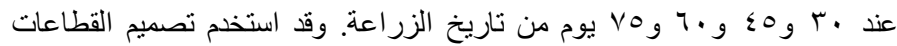
كاملة العشو ائية في التجربة.

وكانت أهم النتائج المتحصل عليها:

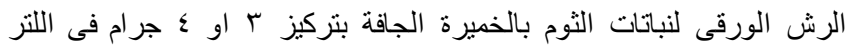

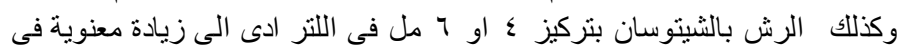

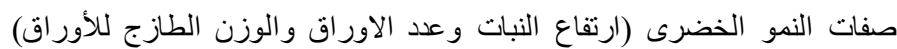

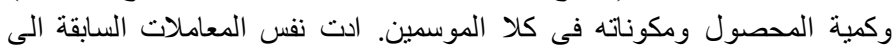

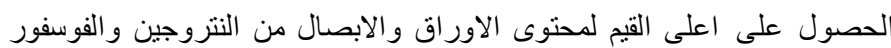

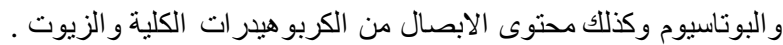

الرش بالثيتوسان بتركيز ؟ او 7 مل فى اللتر ادى الى تحسن القدرة التخزينية

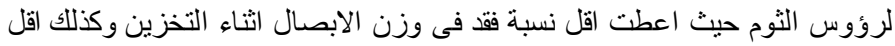
نسبة تزريع و عفن فى كلا الموسمين.

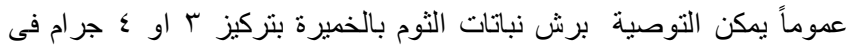

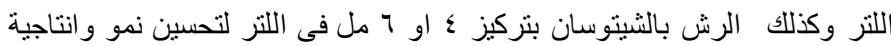

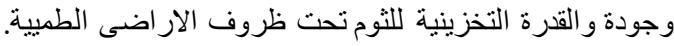

